\title{
The effect of fenfluramine on glucose tolerance, insulin, lipid and lipoprotein levels in patients with peripheral arterial disease
}

\author{
B. P. BuISS \\ M.S., F.R.C.S. \\ C. J. C. KIRK \\ R. G. Newall \\ Department of Surgery, Charing Cross Hospital Medical School, London, W.C.2
}

\begin{abstract}
Summary
An investigation has been undertaken to determine the effects of fenfluramine on glucose tolerance, insulin, fasting lipid and lipoprotein levels, in a series of twenty-five patients suffering from peripheral arterial disease.

The results indicate that fenfluramine significantly improved glucose tolerance and that this was not the result of increased insulin production. Small but significant reduction in fasting cholesterol and $\beta$ lipoprotein levels also occurred in most of the patients. Fenfluramine had no consistent effect on fasting nonesterified fatty acid, glycerides or pre- $\beta$ lipoproteins.
\end{abstract}

\section{Introduction}

Abnormalities of glucose tolerance and fasting lipid levels are present singly or in combination in a major proportion of patients suffering from ischaemic heart disease (Carlson \& Wahlberg, 1966) and peripheral vascular disease (Bliss, Kirk \& Newall, 1972).

It is currently fashionable to treat lipid abnormalities by diet (Frederickson et al., 1970) or with various lipid-lowering agents (Strisower, Adamson \& Strisower, 1968), although the effectiveness of such therapy in preventing deterioration of the vascular lesions has yet to be demonstrated.

Treatment of the abnormalities of glucose tolerance is also undergoing trial and the use of tolbutamide has met with some measure of success (Keen et al., 1968; Paasikivi, 1970).

Fenfluramine has been shown to increase muscle uptake of glucose (Butterfield \& Whichelow, 1968). In young healthy adults it promotes fat mobilization, decreasing triglycerides and increasing non-esterified fatty acid levels (Pawan, 1969). It might, therefore, be expected to reduce or reverse some of the biochemical abnormalities found in atherosclerosis.

This report describes the results of a trial to determine the effect of fenfluramine on glucose tolerance, insulin, lipid and lipoprotein levels in twenty-five patients suffering from peripheral arterial disease.

\section{Subjects}

This study has been made on twenty-five male patients aged between 49 and 69 years, presenting with symptoms and signs of peripheral arterial disease. In each instance the diagnosis of occlusive peripheral arterial disease in the aorto-iliac or femoro-popliteal segments has been confirmed by arteriography. The series reported here forms part of a larger series of fifty cases in whom glucose tolerance, lipid and lipoprotein levels have been studied and which has been reported elsewhere (Bliss et al., 1972). Female patients, patients over 70 years of age and patients with known diabetes or with aneurysms have been excluded. With these exceptions the patients admitted to this investigation form a consecutive series. They have been included in the trial whether or not abnormalities of glucose tolerance or fasting lipids were present.

The patients were not obese, the average triceps skinfold thickness being $7.5 \mathrm{~mm}$, a figure well to the low side of normal. Seltzer \& Mayer (1965) regarded a triceps skinfold thickness in excess of $23 \mathrm{~mm}$ in males between 30 and 50 years, as being necessary to support a definite diagnosis of obesity. In our series only one patient had a triceps skinfold thickness in excess of $15 \mathrm{~mm}$ and in none was it greater than $20 \mathrm{~mm}$.

\section{Methods}

The trial was conducted in such a way that each patient acted as his own control. Each patient was asked to attend the laboratory between 9.0 a.m. and 10.30 a.m. after an overnight fast in which he was allowed nothing to eat or drink or smoke. A fasting blood sample was obtained, following which a standard intravenous glucose tolerance test was performed using $25 \mathrm{~g}$ glucose and blood samples 
drawn at $10 \mathrm{~min}$ intervals for $60 \mathrm{~min}$. Oral fenfluramine therapy was then instituted at a dose of $20 \mathrm{mg} \mathrm{b.d}$. in the first week, $40 \mathrm{mg}$ b.d. in the second week and $60 \mathrm{mg}$ b.d. thereafter, to a total of 6 weeks' treatment. The treatment continued up to and including the evening prior to the second test.

For the second test the patients returned to the laboratory and the intravenous glucose tolerance test was repeated under exactly similar conditions.

Patients were asked to continue on their normal diet and to maintain their usual activities throughout the period of the trial.

Blood glucose, insulin, non-esterified fatty acids (NEFA), cholesterol, glyceride glycerol and lipoprotein estimations were made on fasting blood samples and blood glucose and insulin estimations on the 10-min samples after intravenous glucose. Glucose tolerance was assessed on the basis of fasting blood glucose, glucose utilization constant (K glucose) and the 60-min blood glucose level.

In each patient the triceps skinfold thickness was measured before treatment. The weights of the patients were recorded before and after fenfluramine therapy.

Blood glucose estimations were by the method of Gutteridge \& Wright (1968); immunoreactive insulin by the method of Hales \& Randle (1963), modified by the Radio Chemical Centre, Amersham; nonesterified fatty acids (NEFA) by the method of Mosinger (1965); cholesterol by the method of Block, Jarrett \& Levine (1966); glyceride glycerol by the method of Lofland (1969); and lipoproteins by the method of Stone \& Thorp (1966).

For each parameter, normal, borderline and abnormal levels have been set. These levels have been derived from the generally accepted limits for the methods concerned and confirmed from values obtained in a group of twenty healthy young adults aged 18-40 years in our own laboratory.

These limits (Bliss et al., 1972) are as follows:

(1) Fasting blood glucose-normal $<90 \mathrm{mg} / 100$ $\mathrm{ml}$; borderline $90-100 \mathrm{mg} / 100 \mathrm{ml}$; abnormal $>100$ $\mathrm{mg} / 100 \mathrm{ml}$.

(2) $\mathrm{K}$ glucose-normal $>1 \cdot 4$; abnormal $<1 \cdot 0$.

(3) $60 \mathrm{~min}$ blood glucose-normal $<110 \mathrm{mg} / 100$ $\mathrm{ml}$; abnormal $>130 \mathrm{mg} / 100 \mathrm{ml}$.

(4) Insulin-normal 4-30 $\mu$ units/ml; abnormal $>30 \mu$ units $/ \mathrm{ml}$.
(5) NEFA—normal $<0.9 \mathrm{mEq} / 1$; abnormal $>1.0$ $\mathrm{mEq} / \mathrm{l}$.

(6) Cholesterol-normal $<250 \mathrm{mg} / 100 \mathrm{ml}$; abnor$\mathrm{mal}>270 \mathrm{mg} / 100 \mathrm{ml}$.

(7) Glyceride glycerol-normal $<18 \mathrm{mg} / 100 \mathrm{ml}$; abnormal $>20 \mathrm{mg} / 100 \mathrm{ml}$.

(8) Lipoproteins-using the arbitrary units of Stone \& Thorp (1966) for $\beta$ and pre- $\beta$ lipoproteins the cut-off point between normal and abnormal values is taken as 4.0 units. This is equivalent to three standard deviations from the mean.

\section{Results}

Of the twenty-five patients admitted to the trial one defaulted, failing to return for the post-fenfluramine studies. One other patient experienced severe diarrhoea on fenfluramine therapy and was forced to withdraw from the trial, leaving twenty-three patients for evaluation. Of these twenty-three patients, three other patients complained of diarrhoea but were able to complete the course of treatment. Other side-effects included depression in two patients, whilst one other felt 'wonderfully well' during his course of treatment. For various reasons, technical or chemical, individual parameters were not obtained in some of the cases. This accounts for the variation in total numbers of results for each parameter shown in the tables.

\section{(1) Glucose tolerance}

The effect of the 6-week course of fenfluramine on fasting blood glucose, $\mathrm{K}$ glucose and $60-\mathrm{min}$ blood glucose levels is shown in Table 1.

Most of the patients demonstrated an increase in glucose utilization as shown by a reduction in fasting glucose levels, an increase in $\mathrm{K}$ glucose and a decrease in the 60-min glucose levels. When the mean levels of each parameter in the pre- and post-treatment tests are compared these changes are statistically significant in each case. The values for $P$ are shown in the Table.

Table 4 shows the effect of fenfluramine on those patients whose pre-treatment values were in the abnormal range. It may be seen that the decrease in fasting blood glucose and 60-min blood glucose levels and the increase in $\mathrm{K}$ glucose values are more marked in this group than for the series as a whole. In particular, where the abnormal pre-treatment $\mathrm{K}$

TABLE 1. Effect of fenfluramine on glucose tolerance

\begin{tabular}{lcccr}
\hline & $\begin{array}{c}\text { Raised } \\
\text { (no. and mean increase) }\end{array}$ & $\begin{array}{c}\text { No change } \\
\text { (no.) }\end{array}$ & $\begin{array}{c}\text { Lowered } \\
\text { (no. and mean decrease) }\end{array}$ & $P$ \\
\hline Fasting blood glucose & $3(9 \mathrm{mg})$ & 1 & $19(13 \mathrm{mg})$ & $0.05>P>0 \cdot 02$ \\
K glucose & $15(0.5)$ & 2 & $6(0 \cdot 3)$ & $0.02>P>0.01$ \\
60 -min blood glucose & $5(10 \mathrm{mg})$ & 1 & $16(25 \mathrm{mg})$ & $P<0.01$ \\
\hline
\end{tabular}


glucose values were in the diabetic range these were corrected into the borderline or normal range in five of the six patients. The $60-\mathrm{min}$ blood glucose levels in these same patients were also considerably reduced, the improvement in three being into the borderline or normal range.

\section{(2) Insulin}

The effects of the 6-week course of fenfluramine on the fasting insulin, and also on the peak and 60-min insulin levels after intravenous glucose, are shown in Table 2.

In some patients insulin levels are increased and in others decreased, without any consistent pattern. There is no statistically significant difference between mean levels of insulin in the pre-treatment and posttreatment tests.

\section{(3) Fasting lipid levels}

The effects of the 6-week course of fenfluramine on fasting levels of NEFA, cholesterol, glyceride glycerol, $\beta$ and pre- $\beta$ lipoproteins are shown in Table 3.

There is no significant difference in NEFA, glyceride glycerol and pre- $\beta$ lipoproteins in the preand post-fenfluramine periods.

There is, however, a small, but statistically significant, reduction in the cholesterol and $\beta$ lipoprotein levels following treatment.

In Table 4 the effect of fenfluramine on patients with abnormal pretreatment levels of fasting cholesterol and $\beta$ lipoprotein is shown. Again the effects are greater in this group than for the series as a whole. There were nine such patients. Seven showed a fall in cholesterol levels, with a mean reduction of $47 \mathrm{mg}$ / $100 \mathrm{ml}$, and six a fall in $\beta$ lipoproteins with a mean reduction of 0.7 unit. In four of these patients the reduction in fasting cholesterol and in five the reduction in fasting $\beta$ lipoproteins was sufficient to bring the post-treatment level into the borderline or normal range:

Evaluation of the results in patients with abnormal pre-treatment levels of NEFA, glyceride glycerol and pre- $\beta$ lipoproteins did not alter the findings described for the series as a whole.

\section{Weight changes}

Since fenfluramine is currently marketed as an anti-obesity agent some variation in weight following the course of treatment might be expected, although we instructed our patients to maintain a normal diet. When pre- and post-treatment weighings are compared, however, most patients show only small variations with increases or decreases of $\frac{1}{2}-1 \mathrm{lb}$. Three patients lost significant amounts of weight4,5 and $10 \mathrm{lb}$ respectively, whilst the weight of one patient increased by $2 \frac{1}{2} \mathrm{lb}$. Diarrhoea as a side-effect did not seem to influence the weight changes.

\section{Discussion}

In a series of twenty-five patients suffering from peripheral arterial disease the effects of fenfluramine were significantly to improve glucose tolerance and reduce the fasting cholesterol and $\beta$ lipoprotein levels. There was no significant change in nonesterified fatty acid, glyceride glycerol or pre- $\beta$ lipoproteins, nor in insulin levels.

TABLE 2. Effect of fenfluramine on plasma insulin levels

\begin{tabular}{lcccr}
\hline & $\begin{array}{c}\text { Raised } \\
\text { (no. and mean increase) }\end{array}$ & $\begin{array}{c}\text { No change } \\
\text { (no.) }\end{array}$ & $\begin{array}{c}\text { Lowered } \\
\text { (no. and mean decrease) }\end{array}$ & $P$ \\
\hline $\begin{array}{c}\text { Fasting insulin } \\
\quad(\mu \text { units/ml) }\end{array}$ & $7(3)$ & 1 & $14(3)$ & $0.5>P>0.2$ \\
$\begin{array}{c}\text { Peak insulin } \\
\quad(\mu \text { units/ml) }\end{array}$ & $8(4 \cdot 5)$ & 1 & $10(11)$ & $P>0 \cdot 5$ \\
$\begin{array}{c}60 \text {-min insulin } \\
(\mu \text { units/ml) }\end{array}$ & $8(2 \cdot 5)$ & 3 & $10(5 \cdot 5)$ & $0 \cdot 2>P>0 \cdot 1$ \\
\hline
\end{tabular}

TABLE 3. Effect of fenfluramine on fasting lipid levels

\begin{tabular}{lcccc}
\hline & $\begin{array}{c}\text { Raised } \\
\text { (no. and mean increase) }\end{array}$ & $\begin{array}{c}\text { No change } \\
\text { (no.) }\end{array}$ & $\begin{array}{c}\text { Lowered } \\
\text { (no. and mean decrease) }\end{array}$ & $P$ \\
\hline $\begin{array}{l}\text { NEFA } \\
(\mathrm{mEq} / \mathrm{l})\end{array}$ & $8(0.28)$ & 0 & $10(0.28)$ & $P>0.5$ \\
$\begin{array}{c}\text { Cholesterol } \\
(\mathrm{mg} / 100 \mathrm{ml})\end{array}$ & $6(34)$ & 1 & $16(36)$ & $0.05>P>0.02$ \\
$\begin{array}{c}\text { Glyceride } \\
\text { glycerol (mg/100 ml) }\end{array}$ & $5(4)$ & 2 & $13(3)$ & $0.5>P>0.2$ \\
$\begin{array}{c}\boldsymbol{~} \text { lipoproteins } \\
\quad \text { (arbitrary units) }\end{array}$ & $7(0.4)$ & 1 & $15(0.5)$ & $0.05>P>0.02$ \\
$\begin{array}{c}\text { Pre- } \beta \text { lipoproteins } \\
\text { (arbitrary units) }\end{array}$ & $11(0.8)$ & 0 & $11(0.8)$ & $P>0.5$ \\
\hline
\end{tabular}


TABLE 4. Effect of fenfluramine in patients with abnormal pre-treatment values of glucose tolerance, cholesterol or $\beta$ lipoproteins

\begin{tabular}{|c|c|c|c|c|c|}
\hline & Cases & $\begin{array}{c}\text { Raised } \\
\text { (no. and mean increase) }\end{array}$ & $\begin{array}{l}\text { No change } \\
\text { (no.) }\end{array}$ & $\begin{array}{c}\text { Lowered } \\
\text { (no. and mean decrease) }\end{array}$ & Improvement \\
\hline Fasting glucose & & & & & \\
\hline $\begin{array}{l}>90 \mathrm{mg} / 100 \mathrm{ml} \\
\mathrm{K} \text { glucose }\end{array}$ & 5 & $\mathbf{0}$ & 0 & $5(33 \mathrm{mg} / 100 \mathrm{ml})$ & 5 to $<90 \mathrm{mg} / 100 \mathrm{ml}$ \\
\hline $\begin{array}{l}<1 \cdot 0 \\
60-\text { min glucose }\end{array}$ & 6 & $5(0.4)$ & 0 & $1(0 \cdot 1)$ & 5 to $>1.0 \mathrm{~K}$ glucose \\
\hline $\begin{array}{l}>130 \mathrm{mg} / 100 \mathrm{ml} \\
\text { Cholesterol }\end{array}$ & 6 & 0 & 0 & $6(36 \mathrm{mg} / 100 \mathrm{ml})$ & 3 to $<130 \mathrm{mg} / 100 \mathrm{ml}$ \\
\hline $\begin{array}{l}>270 \mathrm{mg} / 100 \mathrm{ml} \\
\beta \text { Lipoprotein }\end{array}$ & 9 & $2(14 \mathrm{mg} / 100 \mathrm{ml})$ & 0 & $7(47 \mathrm{mg} / 100 \mathrm{ml})$ & 4 to $<270 \mathrm{mg} / 100 \mathrm{ml}$ \\
\hline$>4.0$ units & 9 & 2 (0.2 unit) & 1 & $6(0.7$ unit $)$ & 5 to $<4.0$ units \\
\hline
\end{tabular}

In the series, six patients had abnormal glucose tolerance and in five of these the glucose utilization constant ( $\mathrm{K}$ glucose) was improved into the normal or borderline range. Nine patients had abnormal fasting cholesterol levels and raised $\beta$ lipoproteins. Of these six patients had their abnormality improved, four into the normal range, one was unchanged and in two the levels were slightly increased after treatment.

The changes brought about by fenfluramine therapy could be seen whether or not the patients had abnormal pre-treatment levels but were more marked in the former group.

Since there was no change in fasting insulin nor in insulin secretion following intravenous glucose, it would seem that the changes in glucose tolerance were not mediated through changes in insulin. This would support the findings of Butterfield \& Whichelow (1968) that fenfluramine acts to increase muscle uptake of glucose. Since insulin has been implicated as a possible causative agent in atherosclerosis (Stout $\&$ Vallance-Owen, 1969) there may be some doubt regarding the use of agents which improve glucose tolerance by increasing insulin levels, such as the sulphonylurea group of drugs, despite the favourable findings of Paasikivi (1970) using tolbutamide. In this context the effectiveness of fenfluramine in improving glucose tolerance without raising insulin levels may be important.

The improvement in glucose tolerance could be due to weight reduction but this did not appear to be the case in our series since only three patients lost significant amounts of weight. Furthermore VallanceOwen (1971) believes that the improvement in glucose tolerance in obese patients treated by dietary restriction is due to reduction of carbohydrate intake rather than to loss of weight. Our patients were instructed to maintain a normal diet during fenfluramine therapy.

Pawan (1969) in a group of healthy young adults found that fenfluramine reduced fasting triglyceride levels, increased fasting NEFA levels but had no effect on cholesterol. It was therefore surprising to find that in this group of patients with peripheral arterial disease fenfluramine produced no consistent effect on fasting NEFA, glyceride or pre- $\beta$ lipoprotein levels. Conversely, a significant reduction of fasting cholesterol and $\beta$ lipoprotein levels resulted in most cases. Apart from the presence of arterial disease the reason for this discrepancy in the effect of fenfluramine is not apparent.

The effect of fenfluramine on fasting cholesterol levels and on $\beta$ lipoproteins was small. Although in some patients the abnormality was corrected into the normal range it is unlikely that the degree of reduction will be sufficient to help most patients suffering from hypercholesterolaemia. Fenfluramine may, however, prove to be a useful adjunct, especiallys when the lipid abnormality is associated with imo paired glucose tolerance, as is the case in many of these patients (Bliss, 1971).

\section{Acknowledgments}

We wish to express our thanks to Servier Laboratories Ltd for the supplies of fenfluramine used in this study. We also wish to thank ICI Ltd for providing the nephelometer used to measure lipoproteins, and for the help and encouragement of Dr J. M. Thorp of ICI in the application of this method.

\section{References}

Buiss, B.P. (1971) Abnormalities in glucose tolerance and lipid levels in patients with peripheral arterial occlusive disease. British Journal of Surgery, 58, 306.

Bliss, B.P., KIRK, C.J.C. \& NewAll, R.G. (1972) Abnormalities in glucose tolerance, lipid and lipoprotein levels in patients with atherosclerotic peripheral arterial disease. Angiology (in press).

Block, W.D., JARRetT, K.J. \& Levine, J.B. (1966) An improved automated determination of serum total cholesterol with a single colour reagent. Clinical Chemistry, 12, 681 .

ButTerfield, W.J.H. \& Whichelow, M.J. (1968) Fenfluramine and muscle glucose uptake in man. Lancet, ii, 109.

Carlson, L.A. \& Wahlberg, F. (1966) Serum lipids, intravenous glucose tolerance and their interrelation studied in ischaemic cardiovascular disease. Acta medica scandinavica, $180,307$.

Frederickson, D.S., LeVy, R.I., Jones, E., Bonnell, M. \& ERNST, N. (1970) Dietary Management of Hyperlipoproteinaemias - A Handbook for Physicians. National Heart and Lung Institute, Bethesda, Maryland. 
Gutteridge, J.M. \& Wright, E. (1968) A simple automated guaicum glucose-oxidase method. Journal of Medical Laboratory Technology, 25, 385.

Hales, C. N. \& RaNDLE, P.J. (1963) Immunoassay of insulin with insulin antibody precipitate. Lancet, i, 200.

Keen, H., Jarrett, R.J., Chlouverakis, C. \& Boyns, D.R. (1968) The effect of treatment of moderate hyperglycaemia on the incidence of arterial disease. Postgraduate Medical Journal 44, Suppl. 960.

LoflAND, H. B., Jr (1964) A semi-automated method for determination of triglycerides in serum. Analytical Biochemistry, 9, 393.

Mosinger, F. (1965) Photometric adaption of Dole's microdetermination of free fatty acids. Journal of Lipid Research, $6,157$.

PAASIKIVI, J. (1970) Long-term tolbutamide treatment after myocardial infarction. Acta medica scandinavica, Suppl. 507.
PawaN, G.L.S. (1969) Effect of fenfluramine on blood lipids in man. Lancet, i, 498.

Seltzer, K.C. \& Meyer, J. (1965) A simple criterion of obesity. Postgraduate Medicine, 38, A.101.

Stone, M.C. \& Thorp, J.M. (1966) A new technique for the investigation of the low density lipoproteins in health and disease. Clinica chimica acta, 14, 812.

Stout, R.W. \& Vallance-OWen, J. (1969) Insulin and athermoma. Lancet, i, 1078.

Strisower, E.H., Adamson, G. \& Strisower, B. (1968) Treatment of hyperlipidaemias. American Journal of Medicine, 45, 488.

VAllance-OWEN, J. (1971) discussion on paper by Turtle J.R. Australian and New Zealand Journal of Medicine, 1, Suppl. 2, 20. 